\title{
Team and Project Based Learning for a Sophomore Course on Digital System Design
}

\author{
Pradeep Waychal \\ SVKM'S NMIMS, Shirpur \\ Pradip.waychal@gmail.com
}

\begin{abstract}
The paper describes our experience of using team-and project-based learning (TBL PBL) instructional strategy, which, despite strong evidence of efficacy, is underused - especially - in the early years of engineering education. We describe our framework FAME (form, allocate, monitor and evaluate) for operationalizing the strategy and illustrate it's usage for a sophomore course in digital system design. We found that the strategy resulted in students understanding basic concepts well and utilizing them in developing real life applications as well as developing teamwork, self-learning, and time management skills. We believe that the framework and our experience can be helpful to other faculty members to implement the TBL PBL strategy in their courses.
\end{abstract}

Keywords: Project Based Learning, Team Based Learning, Digital System Design

\section{Pradeep Waychal}

SVKM'S NMIMS, Shirpur

Pradip.waychal@gmail.com

\section{Introduction}

Globally, engineering education is being shaped by three forces - the rapid advances of the Internet and allied technologies [1], the emphasis on outcomebased education [2], and challenges of the 21st century [3]. To tackle these forces, educational researchers are developing and proposing various instructional strategies. Team-based and Projectbased Learning (TBL-PBL) is one of the most important strategies. It emulates real-world environment that enhances learning, and based on the Self-Deterministic Theory (SDT) increases intrinsic motivation [4]. Overall, the strategy helps in improving learning and in dealing with the three forces.

This paper describes our experience of teaching a sophomore course in Digital System Design in the Computer Engineering and Information Technology programs. The course consisted of three credits for theory and two for practical resulting in 42 hours of theory classes and practical sessions each. Traditionally, the laboratory sessions consist of experiments of verifying functionalities of different components and building simpler systems. We decided to adopt a different approach by using TBLPBL and developed a framework called FAME Form, Allocate, Monitor and Evaluate to operationalize the strategy. In the initial two weeks of theory classes, we covered the basic digital components and challenged students to think of reallife applications that they could develop using these 
components. We then randomly formed diverse teams of 5-6 people each. The project selection was left to the teams. Every team discussed the real life applications ideas of its members and chose any one or hybrid of them as their project. The faculty moderated this selection process to ensure right sized and scoped projects. The monitoring of project, team functioning and learning consisted of regular checking of status and solving difficulties. We supported students to incorporate concepts such as, Karnaugh maps, Quine McClusky methods - which were taught in the subsequent theory classes - into their projects. We also carried out team functioning assessment using the instrument developed by Ofori, et al. [5] and used ethnographic study to assess their learning.

The major contribution of this paper is the introduction of a framework for operationalizing TBL-PBL strategy. The framework is illustrated with a course on Digital System Design. The illustration shows that TBL-PBL helps students learn team skills and subject concepts better than traditional approaches and students also enjoy the experience. We believe that the study presents the possibility of remodeling such design courses to significantly enhance acquisition of team skills and subject knowledge. The next section covers literature survey. It is followed by a section that describes the proposed framework FAME and the design of the experiment. At the end, we present our results and concluding remarks.

\section{Literature Survey}

The literature survey starts with various reports prepared by apex engineering education bodies that highlight requirements of the upcoming engineering graduates. It is observed that they can be better met with the help of TBL-PBL strategy. The survey then covers basics of teams, TBL and PBL followed by examples of universities where the strategy is deployed and its associated results. We then provide evidences of benefits of the strategy as reported by many researchers.

The National Academy of Engineeringand Spinks, et al. [6] have identified team work as one of the characteristics of the engineers. The teamwork can also help develop many other characteristics such as, communication, leadership, creativity and socialskills [7]. The National Science Foundation report [8] has emphasized among other things, usage of team-based learning (TBL), and project-based learning (PBL).
Salas, et al.[9] have noted that teams are a critical and essential part in most organizations as they combine different views, multiple skills, diverse experiences, analytical judgments and rich knowledge. Sibley [10] has quoted definition of team-based learning as given by Sweet: 'Team-Based Learning is a special form of collaborative learning using a specific sequence of individual work, group work and immediate feedback to create a motivational framework in which students increasingly hold each other accountable for coming to class prepared and contributing to discussion'. They have also added that TBL brings in paradigm changes in terms of the course goal shifting from knowing to applying, the teacher changing his role from "sage on stage" to "guide at side" as voiced by Murray GellMann, students becoming more active and taking responsibility for learning. Michaelsen [11] has noted that team learning allows efficient use of instructional resources without sacrificing the ability to develop higher level cognitive and social skills of students and building and maintaining enthusiasm of faculty members. Prince and Felder [12] have described project-based learning as follows. It begins with an assignment to carry out one or more tasks that lead to the production of a final product - a design, a model, a device or a computer simulation. The culmination of the project is normally à written and/or oral report summarizing the procedure used to produce the product and presenting the outcome.

Aalborg University, right from its inception- in 1974 -, has been using project-centered engineering programs and producing graduates that are stronger in team skills, communication, ability to carry out a total project and generally more adaptable, and thus, more employable on graduation [13]. The studies of project-based learning and associated benefits are reported at University of Rosklide Denmark, Bremen, TU Berlin, Dortmund and olden berg in Germany, Delft and Wageningen in the Netherlands, Monash and Central Queensland in Australia, and Olin in the US [12]. They also report trends of introducing projects in the first year. Prince and Felder [12] have noted superior outcomes of using PBL at the University of Louvain.

Acar and Newman [14] narrate their experience of first and second year students doing PBL-based project work with the help of final year students. Perrenet, et al.[15] believe that PBL can be further developed in engineering education to bridge the gap between theory and practice in a gradual way. They view that the PBL, in early years, helps in motivating 
and cognitive aspects better than the conventional teaching approach and, in later years, allows taking on more open and complicated problems. Mills and Treagust [13] has concluded that students who use PBL demonstrate higher motivation, better communication and teamwork skills, and better understanding of issues of professional practice and ability to apply their learning to real-life problems. They havecautioned that the strategy may result in weaker engineering fundamentals and unhappinessdue to the time and effort required by projects and the interpersonal conflicts in the teams.

Prince and Felder [12] have found that inductive methods like Project and Team-based learning help students adopt deeper approach to learning [16], challenge dualistic type of thinking [17], and acquire critical thinking and self-directed learning skills thereby helping achieve a broad range of learning outcomes. Bell [7] has explained Project-Based Learning (PBL) as a student-driven, teacherfacilitated approach to learning and claimed that it helps students develop 21stcentury skills. Mills, et al. [13] argue that project-based learning is the best way to satisfy the current industry needs. Lehman [18] has found that TBL helps students in developing diverse process competencies such as problem solving, collaboration, project planning, and communication, besides technical knowledge and skills. Dym[19] has provided sufficient evidence that the first year projects - corner-stone projects - have been proving very useful in increasing retention and quality of engineers. Medical schools [20] have demonstrated that students who are taught with PBL turn out to be better practitioners, than those taught by lecture.

Dyer [21] has cautioned difficulties in administering the strategy. It is not just putting students into study or project teams and grading them. One must spend time in helping students understand how a good team functions and how to manage the group problems that may arise. In the absence of that, students may end up with a negative feeling about team activities as they join the work force.

Thus the benefits of TBL-PBL are articulated well by policy makers and proven emphatically by researchers - albeit more in qualitative than quantitative way.

\section{The Fame Framework}

So the team-and project-based learning experiment cannot be just a matter of forming teams and expecting them to learn. It also includes studying various aspects of the approach and depending on the course / program under consideration, profile of students, size of the class, etc. - making well-thought and conscious choices. This requires a framework. Nelson [22] has suggested different phases of problem solving through design as naming (identifying main issues in the problem), framing (establishing the limits of the problem), moving (taking an experimental design action), and reflecting (evaluating and criticizing the move and the frame) but has not elaborated on various decision steps involved in these phases. Star Legacy Modules [23, 24] has identified various stages of problem or project based learning like challenge, perspectives and resources, assessment andwrap-up. [24]. Both the frameworks focus more on project-based learning and does not cover various aspects of team functioning.

Based on our review of literature on the projectbased and team-based learning, we identified four distinct phases of the instructional strategy- Team Formation, Task Allocation, Monitoring of team, task and learning and Evaluation of students, faculty and the course. We are, therefore, proposing a framework - FAME that stands for Form, Allocate, Monitor and Evaluate. (Figure 1). In the Form phase, one has to decide on team formation, training students and TAs on team functioning fundamentals and ensure that teams develop contracts that form the basis of their functioning. In the Allocate phase, the task types such as, study assignments, small projects or a semesterlong project are to be decided and its allocation worked on. In the light of task allocation, contract reviews become useful. The Monitor phase consists of monitoring the allocated tasks, team functioning and learning. The Evaluation phase requires decision on methods to assess students, course and faculty as well as determining work products to be delivered by the teams.

Some of the possible options for each decision are given in the table 1 . 


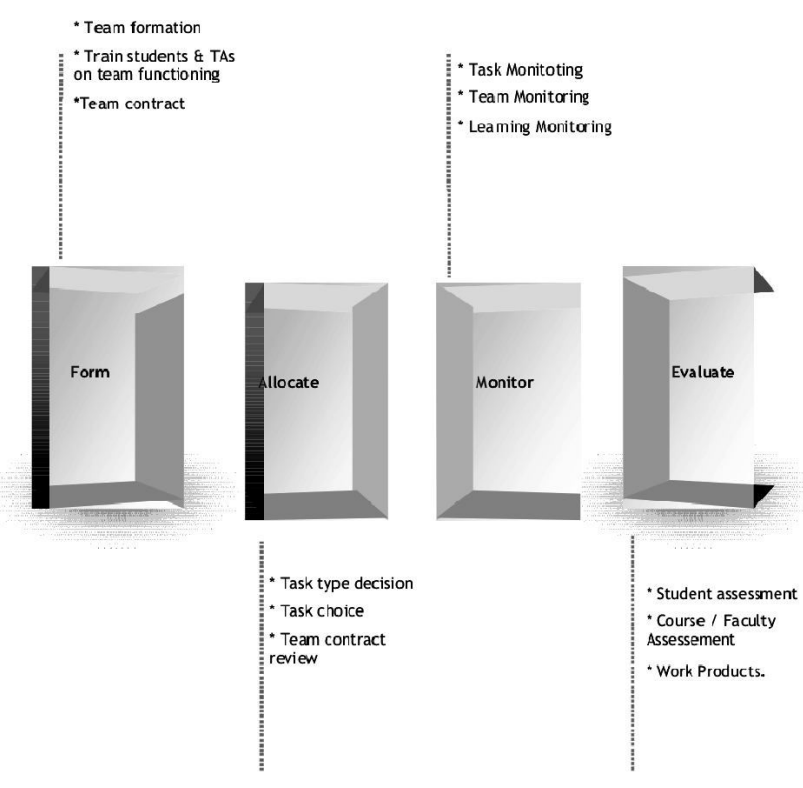

Figure 1: The Proposed Framework

Teams can be formed by students themselves or by faculty. Students could use their social affinity, professional interests and personality types or various combinations of the above to form teams. Faculty could use a structured or random allocation method to ensure diversity. Students and TAs require to be trained in team functioning through a class session or a workshop or through guided self-study methods. Team contracts can be written by students in an ad-hoc way or by studying some earlier contracts or discussing contracts with peer teams.

Task type can be study of assignments, multiple small projects or a semester-long project. The task can be allocated by faculty, chosen by students from a set of tasks floated by faculty or chosen by students and moderated by faculty for its scope and size. Team contract review happens in the same way as the earlier stage.

Tasks can be monitored through informal or formal meetings or through weekly journals. Monitoring of team functioning can be done through informal meetings or formal assessment tools. Learning can be monitored through ethnographic study, formal examinations or with the help of concept inventory.

Student assessment can be done only by faculty or by students themselves (self-assessment) or their peers. One can use Likert or the constant sum scale. In case of peer rating, there can be discussion about each team member in his absence to decide the final rating.
Course and faculty feedback by students can happen before or after the results. It can also be provided by faculty colleagues. Work products can be combination of written report, presentation, poster, project deliverables such as, specifications, design, user manual and demonstration of working product / prototype.

\section{Research Experiment}

The benefits of rightly executed project-and teambased learning strategy are proven beyond doubts. In this experiment, we are applying the strategy using the FAME framework.

\section{A. Objective and Scope}

The basic objectives of the experiment were to illustrate use of the FAME framework for operationalizing TBL-PBL strategy and proving that the reported benefits of the strategy can be accrued.

The scope was a course on Digital Design of 180 sophomore students of computer engineering and information technology at a premier Indian college. While most of the students were admitted to the four year Undergraduate (UG) engineering program after twelve years of schooling, some (24) had lateral entries in the second year of the program after ten years of schooling followed by three years of engineering diploma. While the college is considered to be the best in the state and attracts bright students, there was noticeable variation in performance of the students at the entrance examinations and in the prior courses of the engineering program.

B. Designing the strategy: We have developed the framework FAME for putting the TBL-PBL strategy in operation. It consists of four phases - form, allocate, monitor and evaluate and has to be customized for a given class and course. The customization requires taking various decisions that are explained in the forthcoming paragraphs.

\section{1)Form:}

The teams were formed by the faculty member. Hernandez [25] has stated that students are more likely to have a positive learning experience when their teams are selected by faculty. Connerley, et al. observed that faculty-selected teams are not used possibly because of the perception that student- 
selected groups perform better [26]. We argue that while student-selected teams may have fewer issues due to general affinity of the group, they will be robbed of a great learning opportunity. In the professional environment, they have no choice in selecting their team members and have to have skills of teaming up with total and perhaps incompatible strangers.

The teams can be formed in a structured fashion or randomly to design diversity. Song and Grabowski [27] have found that heterogeneous peer groups (those with diversity) perform better than homogeneous ones. Various methods can be used in forming diverse teams. Deibel [28] has tried latent jigsaw method and Felder Silverman Index of Learning Styles. The former assigns groups based on prior student knowledge in order to promote peer-teaching and critical thinking. The latter promotes participation by creating groups that have similar learning styles and creates a familiar social atmosphere to work in. When implemented, each method created a classroom environment in which students were actively engaged and participating with the other members in their groups. We took a position that individuals have so many facets that it is nearly impossible to come up with a perfect mechanism to ensure diversity. For example, when one goes by say academic performance, grades may not be a true reflection of the students' capability - especially with respect to PBL TBL strategy. Further, it depends on whether one looks at grades of the relevant courses or overall grade point performance. Therefore we used the random function in Excel to form teams.

Table 1: The decision points and options in the Proposed Framework

\begin{tabular}{|c|c|c|c|}
\hline Form & Allocate & Monitor & Evaluation \\
\hline Teams formation & Task type decision & Task Monitoring & Student Assessment \\
\hline $\begin{array}{l}\text { Students form team based on } \\
\text { their social affinity, } \\
\text { professional interest } \\
\text { passion or personality types } \\
\text { or various combinations of } \\
\text { the above. }\end{array}$ & $\begin{array}{l}\text { Study assignments } \\
\text { (Inquiry, problem) }\end{array}$ & $\begin{array}{l}\text { Informal } \\
\text { monitoring on } \\
\text { regular basis }\end{array}$ & $\begin{array}{l}\text { Students assess all team members } \\
\text { including themselves using likert } \\
\text { scale, constant sum scale } \\
\text { optionally followed by } \\
\text { discussions in absentia. The } \\
\text { assessment is moderated by } \\
\text { faculty. }\end{array}$ \\
\hline $\begin{array}{l}\text { Faculty forms teams } \\
\text { randomly. }\end{array}$ & $\begin{array}{l}\text { Multiple small } \\
\text { projects (Task / } \\
\text { project) }\end{array}$ & $\begin{array}{l}\text { Formal } \\
\text { presentations and } \\
\text { review on regular } \\
\text { basis }\end{array}$ & Done by Faculty \\
\hline $\begin{array}{l}\text { Faculty forms team using a } \\
\text { structured method. }\end{array}$ & $\begin{array}{l}\text { A semester long } \\
\text { project (Problem } \\
\text { project) }\end{array}$ & $\begin{array}{l}\text { Checking of } \\
\text { weekly journals. }\end{array}$ & $\begin{array}{l}\text { Done by students, moderated by } \\
\text { faculty. }\end{array}$ \\
\hline $\begin{array}{l}\text { Train Students - TAs on } \\
\text { team functioning. }\end{array}$ & Activity Choice & Team Monitoring & Course / Faculty Assessment \\
\hline A class session & Faculty allocates & $\begin{array}{l}\text { Informal meeting } \\
\text { to discuss team } \\
\text { functioning }\end{array}$ & $\begin{array}{l}\text { Students, after announcement of } \\
\text { the course grades }\end{array}$ \\
\hline A class workshop & $\begin{array}{l}\text { Teams choose from } \\
\text { given set of tasks }\end{array}$ & $\begin{array}{l}\text { Using formal } \\
\text { assessment tools } \\
\text { by Ofori, et al. to } \\
\text { assess the } \\
\text { functioning }\end{array}$ & Students, after the examination \\
\hline $\begin{array}{l}\text { Reading articles / watching } \\
\text { videos }\end{array}$ & $\begin{array}{l}\text { Teams come up with } \\
\text { their own ideas and } \\
\text { seek faculty } \\
\text { moderation for right } \\
\text { scoping }\end{array}$ & & $\begin{array}{l}\text { Peers / senior faculty, by talking } \\
\text { to some students and looking at } \\
\text { the course plan, material and } \\
\text { evaluations }\end{array}$ \\
\hline Team Contracts & $\begin{array}{l}\text { Team Contracts } \\
\text { review }\end{array}$ & $\begin{array}{l}\text { Learning } \\
\text { Monitoring }\end{array}$ & Work Products \\
\hline $\begin{array}{l}\text { Students study some } \\
\text { contracts and write them }\end{array}$ & $\begin{array}{l}\text { Students study some } \\
\text { contracts and write } \\
\text { them }\end{array}$ & Concept Inventory & $\begin{array}{l}\text { Written Report, Presentation, } \\
\text { Poster, Project deliverables like } \\
\text { specs, design, user manual }\end{array}$ \\
\hline Students write on their own & $\begin{array}{l}\text { Students write on } \\
\text { their own }\end{array}$ & $\begin{array}{l}\text { Ethnographic } \\
\text { study }\end{array}$ & $\begin{array}{l}\text { Demonstration of working } \\
\text { product / prototype }\end{array}$ \\
\hline $\begin{array}{l}\text { Teams discuss with other } \\
\text { teams. }\end{array}$ & $\begin{array}{l}\text { Teams discuss with } \\
\text { other teams. }\end{array}$ & $\begin{array}{l}\text { Formal } \\
\text { examinations }\end{array}$ & \\
\hline
\end{tabular}


A team contract can provide the basis for reliability, consistency, and predictability[29]. We did not organize them, though. Since this was students' first team experience, we felt that they may not be able to draft and use the contracts. We relied on regular monitoring of the team functions instead. We did discover some un-reported conflicts within some teams towards the end of the course and believe that we should have guided and introduced contracts.

\section{2)Allocate:}

Bransford, et al. [30] have found that when students see usefulness of what they are learning and when they can use it to do something that has an impact on others, they feel more motivated. They also have stated that creating work-like environment in courses helps increase the likelihood of building knowledge and skills required at workplaces. McKendall [31] suggests that teams should do a semester-long, sufficiently complex project that requires collective efforts. The project should require group decisions and it should be integrated enough that it cannot be simply broken up and parceled out. We concurred with her views and chose a semester-long project instead of multiple smaller projects or any other type of assignments.

Prince and Felder [12] have observed that allowing students autonomy of choosing their own projects and strategies increases their motivation whereas allocation of projects by faculty increases focus on the course. In order to induce the feeling of "autonomy" in the minds of students, we asked them to choose projectsand moderated theirscope and size.

\section{3) Monitor:}

This instructional strategy demands an indirect but crucial role from faculty members. They have to monitor progress, on a regular basis, on all the fronts tasks, team functioning, and learning. Brooks \& Ammons [32] have emphasized the importance of having peer feedback on individual member's performance at regular intervals. We monitored tasks and team functioning through weekly informal meetings with the teams - as a part of the regular laboratory sessions. Besides, we used Ofori, et al.'s team assessment instrument. We chose it instead of Brown's instrument [33] as it focuses on identified behavioral characteristics of good teamwork that can help in better peer evaluation and has higher reliability[5]. The instrument helped students to understand overall team functioning and their contribution to the team as per their own and peers' perception. We monitored learning with the help of formal examinations. We also had a trained ethnographer interviewing some of the teams, randomly, to assess learning and team functioning. Ethnography involves performing a work practice study of the students to gather information about their experience [35]. Paulette St James [36] has used ethnographic methods to present how caregivers of several occupational groups worked as teammates in one home health organization. We did not find appropriate concept inventory - otherwise that would have been a good choice [37].

\section{4) Evaluate:}

The evaluation phase consists of student, faculty and course assessment and deciding the expected work products. All the details about student assessments such as, the criteria to be used and percentage contribution of them were announced at the start of the course. The work product details were announced prior to evaluations. The final evaluation included demonstration of working systems and poster sessions. The faculty did the overall project assessment and asked students to assess their team peers using the constant sum scale with a clear instruction that the assessment should depend only on quality and quantity of contribution to the project. The final individual assessment was a function of project assessment and peer assessment. McKendall[31] suggests that most of the grades should be collective. He proposes that team members should do self and peer assessment using a standard form and then use team meetings to discuss the performance of each member - in his absence - to decide the final ratings. We did not use the 'in absentia' discussion method. The reason being in such discussions, students with extroversion dominate and color the discussion and results thereof. A faculty member can moderate such discussions but with 180 students that was not possible. The course feedback was provided by the students after their examination.

C. Executing the strategy: The strategy execution consisted of initiation, system and team developmentand closure.

Initiation: This started with students learning the basic building blocks of digital systems such as, gates, flip flops, registers, memory, ADC-DAC, etc. and then thinking of a real-life application that could be built 
using these building blocks. The faculty formed teams. The teams discussed ideas of each member and zeroed on their projects. The faculty moderated project definitions for right size and scope and also announced evaluation criteria as comprehensiveness and novelty of functionality, variety of components and optimization techniques used in design, proper functioning and presentation of the system. The students then learnt a digital circuit simulation tool MMLOGIC.

System and team development: The teams divided the project into blocks and selected one of them for the first simulation. They announced completion of first blocks on the online course management systemMoodle and explored possibility of using the completed blocks of other teams. Then they formed sub-teams and started working concurrently on multiple blocks and acquired project kits consisting of input digital and analog switchboards, output LED boards, bread boards and project-specific components. The teams also underwent a team functioning assessment using Ofori instrument. As they learnt new techniques in theory classes such as Kmap, Quine McClusky, they refined their designs. Some of the teams were also interviewed by an ethnographer to assess their learning.

Closure: In this phase, students demonstrated working systemsand presented their learning in a poster session. They assessed contribution of team members using a constant sum scale method and provided feedback on course and faculty

\section{Results}

We analyzed the outcome of the course through an ethnographer interviewing the students, asking students their top three learnings at the time of the poster session, collecting feedback about the things that they liked and disliked about the course and referring to an article written by a couple of the students on their experience with the course.

\section{1) Ethnographer:}

We had an ethnographer interview some of the teams to understand their learning and experience with the course. The ethnographer provided the following report; "The students felt that they could work on much larger projects in this model. They observed that individual students did less work than they would have had to on a smaller project. The important thing was they worked less, but learned more - due to the collective experience. Further, the learning happened at conceptual levels. Overall the students felt that it was more fulfilling than working alone as teammates were available when they ran into trouble. The model also allowed social interaction within the team which helped them make new friends. Moreover, it helped to learn teaming up with new colleagues." This report clearly implies that the students had a good experience both from the learning and social perspectives. They learned more with less effort and also made good friends.

\section{2) Poster Session and top three learnings}

We had a poster session at the end of the semester. The teams were asked to list their learningfrom the course. We analyzed them to arrive at the following list of learning;

Table 2: Attributes and Number of teams reported learning in the attribute

\begin{tabular}{lc}
\hline \multicolumn{1}{c}{ Learning } & $\begin{array}{c}\text { \# teams reported } \\
\text { learning in the } \\
\text { attribute }\end{array}$ \\
\hline $\begin{array}{l}\text { Coordination and team } \\
\text { work }\end{array}$ & 27 \\
\hline $\begin{array}{l}\text { Practical knowledge } \\
\text { and its application to } \\
\text { solve real life problems }\end{array}$ & 23 \\
\hline $\begin{array}{l}\text { Digital Systems } \\
\text { Concepts }\end{array}$ & 21 \\
\hline $\begin{array}{l}\text { Documentation and } \\
\text { Presentation }\end{array}$ & 5 \\
\hline Time management & 6 \\
\hline Optimization of system & 3 \\
\hline Handling failure & 3 \\
\hline
\end{tabular}

This indicates that the students learnt team work as well as digital system concepts and their application to real-life problems in a better way. Each system worked, if not completely at least partially, and not a single component was burned during demonstration or before that in the whole semester.

3) Course-end feedback on what students liked and disliked about the course

We also sought feedback from the students about what they liked and disliked about the course. Since the course consisted of both theory and practical, the 
feedback covered both the aspects. We have segregated the feedback for the practical part i.e. the team-project based learning and are presenting it below. Since we had 180 students, we have randomly chosen 35 feedback forms and analyzed them by using constant comparison method [38]. The figure $2 \mathrm{a}$ and $2 \mathrm{~b}$ provide the feedback in a graphical form. The former indicates the 'likes' of the students as real-life project, course plan and teamwork with 29,27 and 15 students voting for them, respectively. The $2 \mathrm{~b}$ indicates the dislikes as lab guidance, time constraint and grading system. Of the three, lab guidance and time constraint (they could not devote as much time as they wanted) appeared to be major concerns.

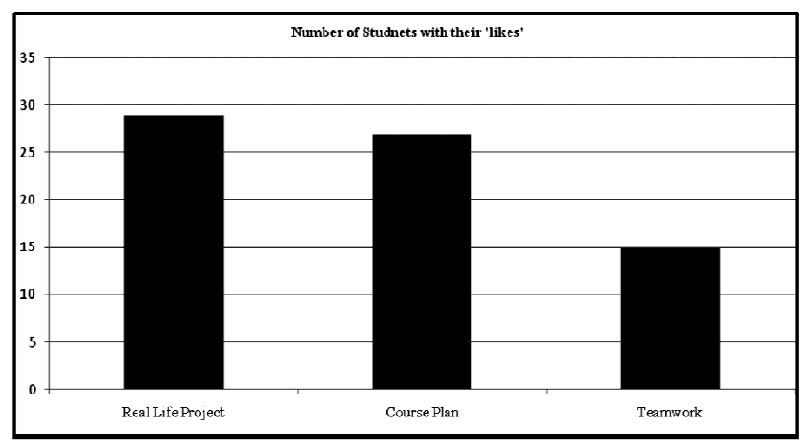

Figure 2b: Course-End Feedback from the students on what they disliked.

4) Feedback from the article written by students

A couple of students wrote an article on their experience of the course. The article concludes as follows; "We compared our learning with another department - that had the same course - where conventional method of conducting practical was used. We found that they did not get any of the benefits that we accrued. They learnt individual components and not their integration to build applications. We earned confidence of using our knowledge to solve real life problems."

Overall the benefits from all the sources seem to converge on ability to apply digital systems' concepts to develop real-life applications and ability to function on teams.

\section{Conclusion}

There has been a general agreement on efficacy of project- and team-based learning instructional strategy. We have made an attempt to develop a framework to construct such experiments, illustrated its usage with a course and have showed that the strategy indeed offers some benefits. The benefits are apparent based on the feedback that teams have given on their three most important learnings, interviews by a trained ethnographer, feedback from individual students about what they liked and disliked about the course and an article written by students describing their experience. The benefits from all the sources seem to converge on ability to apply digital systems' concepts to develop real-life applications and ability to function on teams. This was their first experience with project and team-based learning and it could have been more positive with more guidance.

We introduced more active elements in the experiment by allowing students to choose projects and utilizing constant sum scale peer evaluation. It is pointed out that adopting the TBL-PBL strategy is not all that easy. We believe that the framework and its illustration can support other faculty members to implement the strategy in their courses. We carried out this experiment at the sophomore level which is not a common thing. While there are a few universities that rely on project-based learning right from the first semester, most of them utilize the strategy only in junior YEAR.Students did feel that such strategies should be deployed if not in the freshman at least in the sophomore years.

This study was done in one college and needs to be repeated in different settings based on geographies, culture, class sizes and different faculty members to validate the findings. That will also help us offer concrete suggestions about various options that can be deployed in all the FAME phases. While the framework is a result of using the TBL-PBL strategy in a number of courses and feedback from some faculty colleagues, it still requires more rigorous review and its application in varied areas. Even though the team- and project-based learning has broadly been proven, we did not work with any control group to convincingly prove our claim. Using a control group can enhance the credibility of the benefits of the strategy. The use of personality types based on instruments like MBTI, Belbin in forming teams has to be studied further. Also, different customized interventions will have to be designed and developed so that individuals can improve their team skills. Those interventions will have to be rigorously proved. In a PBL environment, it has been noticed that there may be some gaps in content knowledge. We did not take any specific measure to track the gap and 
devise ways of filling that, which needs to be worked on.

\section{Acknowledgments}

We thank all the students who participated in the experiment. We also thank Prof Ken McIssac of the University of Western Ontario for his support of this research and Prof Jayshri Sabarinathan, Ms Shweta Shinde and Mr Gautam Akiwate and Mr Abhay Joshi for review of the early manuscripts.

\section{References}

[1] Bourne, J., D. Harris, and F. Mayadas, Online Engineering Education: Learning Anywhere, Anytime. Journal of Engineering Education, 2005.94(1):p. 131-146.

[2] Koehn, E., ABET program criteria for educating engineering students. International Conference on Engineering Education, ICEE'99, Paper 413,..(1999), Available on-line athttp://www.fs.vsb.cz/akce/1999/ICEE99/Pro ceedings/papers/413/413.htm.

[3] Grimson, J., Re-engineering the curriculum for the $21 \mathrm{st}$ century. European Journal of Engineering Education, 2002. 27(1): p. 31-37.

[4] Ryan, R.M. and E.L. Deci, Intrinsic and Extrinsic Motivations: Classic Definitions and New Directions. Contemporary Educational Psychology, 2000. 25(1): p. 54-67.

[5] Ohland, M.W. and R.A. Layton. Comparing the reliability of two peer evaluation instruments. in 2000 Annual Conference and Exposition Proceedings. 2000.

[6] Nigel Spinks, N.S.a.D.B., Educating Engineers for the 21st Century: The Industry View. 2006, The Royal Academy of Engineering.

[7] Bell, S., Project-Based Learning for the 21st Century: Skills for the Future. The Clearing House: A Journal of Educational Strategies, Issues and Ideas, 2010. 83(2): p. 39-43.

[8] National Science Foundation, Systemic Engineering Education Reform: An Action Agenda. 1997, National Science Foundation, : www.nsf.gov/cgi-bin/getpub?nsf9827, .

[9] Salas, E., Dickinson, T.L., Converse, S.A. and Tannenbaum, S.I. , ed. Toward an understanding of team performance and training Teams: Their Training and Performance,. ed. R.W.a.S. Swezey, E. 1992, Ablex Publishing Corporation, : Westport, CT,. pp. 3-29.
[10] Sibley, J.S., S. Retrieved February 23, 2011, What is TBL? (2010). The University of British Columbia - Faculty of Applied

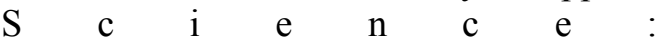
http://www.teambasedlearning.org/.

[11] Michaelsen, L.K., Team Learning: A Comprehensive Approach for Harnessing the Power of Small Groups in Higher Education. Digital Commons@University of Nebraska - Lincoln, 1992.

[12] Prince, M.J. and R.M. Felder, Inductive Teaching and Learning Methods: Definitions, Comparisons, and Research Bases. Journal of Engineering Education, 2006. 95(2): p. 123-138.

[13] Mills, J.E. and D.F. Treagust, Engineering education-Is problem-based or projectbased learning the answer? Australasian Journal of Engineering Education, 2003. 3: p. 2-16.

[14] Acar, B.S., and I.A. Newman, Students as Tutors-Learning Problem-Solving Skills hy Tutoring PBL. IntemationalJournal of Engineering Education, , 2003. 19 (5): p. 712-716.

[15] Perrenet, J.C., P.A.J. Bouhuijs, and J.G.M.M. Smits, The Suitability of Problem-based Learning for Engineering Education: Theory and practice. Teaching in Higher Education, 2000. 5(3): p. 345358.

[16] Entwistle, N., V. McCune, and J. Hounsell, Approaches to studying and perceptions of university teaching-learning environments: Concepts, measures and preliminary findings. Enhancing Teaching and Learning Environments in Undergraduate Courses Occasional Report, 2002. 1.

[17] Perry Jr, W.G., Forms of Intellectual and Ethical Development in the College Years: A Scheme. Jossey-Bass Higher and Adult Education Series. 1999: ERIC.

[18] Lehmann, M., et al., Problem-oriented and project-based learning (POPBL) as an innovative learning strategy for sustainable development in engineering education. European Journal of Engineering Education, 2008.33(3): p. 283-295.

[19] Dym, C.L., et al., Engineering Design Thinking, Teaching, and Learning. Journal of Engineering Education, 2005. 94(1): p. 103-120. 
[20] Barrows, H.S., How to Design a ProblemBased Curriculum for the Preclinical Years. 1985, New York, N.Y.:: Springer Verlag.

[21] Dyer, W., Team building: Current issues and new alternatives. . 1995, Reading, MA: Addison-Wesley.

[22] Nelson, W.A., Problem solving through design. New Directions for Teaching and Learning, 2003.2003(95): p. 39-44.

[23] Star Legacy Modules. Iris Center for Faculty Enhancement, Vanderbilt University.

[24] Mariela A. Rodríguez, J.G.a.P.G.S., Preparing School Leaders to Effectively Support Special Education Programs: Using Modules in Educational Leadership in the Annual Meeting of the University Council for Educational Administration. 2006: San Antonio, Texas

[25] Hernandez, S.A., Team learning in a marketing principles course: Cooperative structures that facilitate active learning and higher level thinking. Journal of Marketing Education, 2002.24(1): p. 73-85.

[26] Connerley, M.L. and F.A. Mael, The Importance and Invasiveness of Student Team Selection Criteria. Journal of Management Education, 2001.25(5): p. 471-494.

[27] Song, H.-D. and B.L. Grabowski, Stimulating intrinsic motivation for problem solving using goal-oriented contexts and peer group composition. Educational Technology Research and Development, 2006. 54(5): p. 445-466.

[28] Deibel, K., Team formation methods for increasing interaction during in-class group work, in Proceedings of the 10th annual SIGCSE conference on Innovation and technology in computer science education. 2005, ACM: Caparica, Portugal. p. 291-295.
[29] Bandow, D., Time to create sound teamwork. Journal for Quality and Participation, 2001. 24(2).

[30] Bransford, J.D., A.L. Brown, and R.R. Cocking, How people learn. 2000, Washington, DC: National Academy Press.

[31] McKendall, M., Teaching Groups to Become Teams. Journal of Education for Business, 2000. 75(5): p. 277-282.

[32] Brooks, C.M. and J.L. Ammons, Free Riding in Group Projects and the Effects of Timing, Frequency, and Specificity of Criteria in Peer Assessments. Journal of Education for Business, 2003.78(5): p. 268-272.

[33] Brown, R. Autorating: Getting individual marks from team marks and enhancing teamwork. in Frontiers in Education Conference, 1995. Proceedings., 1995. 1995. IEEE.

[34] Szymanski, M.H. and J. Whalen, Making work visible: ethnographically grounded case studies of work practice. 2011: Cambridge University Press.

[35] Garfinkel;, H., Studies in Ethnomethodology. . 1967, Englewood Cliffs, NJ: Prentice Hall,.

[36] James, P.S., Interoccupational teamwork in a home health setting: An ethnography, in Faculty of Social Sciences. 1990, University of Denver.

[37] cihub. Available from: https://cihub.org/.

[38] Glaser, B., Strauss, A., The Discoveryof Grounded Theory. . 1967, Hawthorne, NY.: Aldine Publishing Company,. 